\title{
PRINCIPLES AND CONCEPTS IN DESIGNING TROPICAL-SHORE SETTLEMENT IN ESTUARY ECOSYSTEM CASE STUDY: WERIAGAR DISTRICT, BINTUNI BAY
}

\author{
Firmansyah FIRMANSYAH ${ }^{1, *}$, Resya WULANNINGSIH ${ }^{2}$, Bintang NIDIA KUSUMA ${ }^{3}$, \\ Ira Prayuni RANTE ALLO \\ 1, 2, 3, 4 Institut Teknologi Bandung, Indonesia
}

Received 01 September 2017; accepted 18 January 2018

\begin{abstract}
Weriagar District is located in estuary area and is prone to land loss, due to river and coastal erosion. Without any prevention efforts, Weriagar land might be disappear due to erosion on coastal and riverside. The Shore Housing Improvement Program was developed in 2014 to improve the environment, housing and settlement in Weriagar District. Based on the preliminary site observation and further site survey, the program continued in conducting in-depth analysis consists of house assessment method prior to concept select matrix development, in which design criteria were obtained. The results from analysis phase shows that it is necessary to design a house and settlement that can fulfil the needs of indigenous people, both functionally and aesthetically. Functionally, the house is designed to provide spaces for both private and public needs of the family. It can be used either as a family private space or as a public gathering space between family and their neighbours. Aesthetically, houses' architectural form is designed to identify the locality of Weriagar District. The houses' design feature highlighted in using local material, rainwater harvesting system, high pitched roof feature as a response to hot-humid climate and elevated-floor feature as response to tidal condition in estuary area.
\end{abstract}

Keywords: Estuary settlement, settlement development, housing design, design criteria, Weriagar District, Bintuni Bay.

\section{Introduction}

Weriagar District is located in Bintuni Bay Regency, West Papua, Indonesia. Bordered by a river in the northern side and the sea in the southern side. The living community has lived for centuries and inherited custom land law as well as livelihood in fisheries. Due to its location in a change-sensitive estuary area, it had been reavealed that coastal and river erosion threats Weriagar District since fisheries and settlement activites interfere its natural function as riparian-coastal area. Estuary area may provide benefits to local communities, but any settlement pattern must necessarily constrain the baselines for restoration/ rehabilitation or sustainable development goals, as well as identifying the appropriate level of extractive uses that an estuarine environment can support (Weinstein, 2008). The phenomenon of flooding had already become a common to this area throughout the year. Flood prone areas are inevitable since the tide submerged due to global warming. According to the study, the projected sea level rise will increase from the year 2010,2050 , up to 2100 , will rise 0.934 meters from the present, which tends to elimi- nate 115 islands located in Indonesia (Firmansyah, Tamin, Rante Allo, \& Wulanningsih, 2017).

Based on this issue, the Tropical Shore Housing Improvement Program was initiated in early 2013 to save the inhabitants' living quality and to improve the housing and settlement in Weriagar District. The program's goal is to achieve holistic improvement for environment and settlement value improvement. To support the program, a PreFeasibility Study was initiated to represent the program's initiation activity which is aimed to identify the main solution alternatives and recommend the most prospective solution, as well as to formulate a complete improvement program execution activities and schedule. the Pre-Feasibility Study was carried out in three stages, i.e. Site visit, Site survey, and Analysis.

The Analysis phase were carried out in two steps. The first step is Data Analysis where all data collected during the site survey was technically processed, and information gathered were comprehensively analyzed from engineering, economic, social, and environmental points of view.

*Corresponding author. E-mail: firmansyah@ar.itb.ac.id 
The second step of 'Analysis' is Concept Select Matrix Development and Evaluation. The objective of Concept Select Matrix is to develop a matrix system that could analyze the effectiveness of potential option and option modifiers through a defined set of criteria and parameters, and recommend the most prospective solution (Kusliansjah \& Suriansyah, 2013).

The Tropical Shore Settlement Improvement Program was initiated as an effort to rehabilitate physical condition and life quality in Weriagar District. The Rehabilitation activities were intended to support and improve life quality of communities not only in Weriagar District but also in the Bintuni Bay and beyond by providing a reliable and selected resources. The Tropical Shore Settlement Improvement program scope includes House Design and Settlement Rearrangement, as well as Infrastructure Development. This program phase consists of Site Survey, Site Analysis, Concept Select Matrix, Value Improving Practices, and Detailed Engineering Design. This program was intended to obtain the house design that suits with convenience and functionality, but does not eliminate the architecture value both of function and aesthetics of the building. Infrastructure development program consist of improving and complementing the existing of public infrastructure and social facilities in accordance with the regional priorities of development in Weriagar District. The design and development in this program must be based on the ecology, aesthetic, function, and existing building conditions.

\section{Method}

Some problem issues found during site survey were soil erosion and abrasion that risk the settlements and livelihood. Existing soil condition (peat, mud, and tidal) affect the material structure design and construction methods for the settlement development. Utilization of heavy equipment or transportation is limited since there was no proper access to the area. Besides that, Weriagar District is located in a remote area caused some problem, including difficulties in finding clean water, strong wind gusts, frequent occurrence of tidal, so that the house design must be accordance with the weather conditions in the area.

The Shore Settlement Improvement Program was intended to find the most prospective solution to answer the issue through design. The phase of the program was site observation, site survey, data collection through primary and secondary sources, site analysis, concept selection process, to detailed engineering design. Based on the preliminary site observation and further site survey, the program continued in conducting in-depth analysis consists of house assessment method prior to concept select matrix development, in which design criteria were obtained.

\section{Resilient settlement design}

Building settlements and its constituent elements can be categorized as work of vernacular architecture. The term vernacular architecture shows its association with native peoples, ethnic, folk, culture, and traditional architecture itself. In the context of the environment and the resources available, they are usually the owner or a community built, using traditional technology. Vernacular settlements are related to the dwellings, living activity, and neighborhood with different types of local livelihood. Meanwhile, a shore settlement can be understood as a settlement which has a livelihood, economic life, and social life depends on rivers, creeks, or channels in which the location and placement of the settlement are closely related to the geography of the shore (Wijanarka, 2008). In turn, residents living activities will reflect the culture and civilization of the shore (Wicaksono, Siswanto, Kusdiwanggo, \& Anwar, 2016).

There are several factors that can affect the settlement development (Supriharyono, 2007), namely: Geographical Location, Population, Facility and Infrastructure, Economic and affordability of purchasing power, Social and Cultural, Science and Technology, Institutional, and Community Participation. In this Tropical Shore Settlement Improvement program, resilient design is one of the important criteria. Resilient design is needed to protect natural features that provide ecosystem services (Bengen, 2004). The first step in resilient design for inland flooding is to identifying and mapping areas of any existing natural features and resources that provide ecosystem services in absorbing rainfall to develop a plan that protects or restores these features (Watson \& Adams, 2011). These include Swales, depressions, and flow pathways; Wetlands, headwater streams, and stream systems; Vegetation; Geology, soils, and slopes; Geotechnical information for building construction, such as soil borings.

There are some criteria for designing in riparian area (Watson \& Adams, 2011); (a) Rainwater Harvesting as an extension of cisterns, additional measures may include designs to recover and reuse all water that falls on-site through integrated rainwater harvesting; (b) Native Planting once established, native planting requires little or no maintenance and is a cost- effective measure by which to reduce municipal costs and improve environmental benefits by replacing traditional lawn planting and care. They are adapted to local conditions and resistant to local insects; (c) Riparian Buffers are areas established by setbacks from streams, rivers, and wetlands. A riparian buffer preserves the stream's natural characteristics. It filters sediments, nutrients, and chemicals from surface run off and shallow groundwater; (d) Wetland Protection and Restoration. A wetland is an exquisitely complex biological system that cleans water and air and provides a natural sponge for varying water flows (Wicaksono et al., 2016). Where some detention is required for large storm events, newly created wetland areas will improve water quality and create habitat while providing detention

At the building scale, there are some building elements criteria for flood design (Watson \& Adams, 2011). Conditions on waterfront sites are often unsuitable for supporting shallow foundations. Foundations need to be constructed at sufficient depth to prevent undermining 
by eroding soils and scour. Foundation for waterfront structure require substantial bracing to resist hydrodynamic wave and wind forces. Pile foundations typically need bracing bolted to the pilings. Structures should be securely anchored to the pilings with corrosion resistance bolts. For Structure, it should be Wind Resistant Design, the porosity of construction and openings either left open or created during the storm determine the extent of wind penetration to the interior and contribute additive (or subtract from) external pressure. In coastal environments exposed to salt air, corrosion resistant structural connectors are required. Salt is very corrosive to metals, including concrete reinforcement that is exposed over time by cracking or spalling of the concrete. For the material, it should consider the use of flood damage resistant material, The International Building Code (IBC) defines flood damage resistant materials as "capable of withstanding direct and prolonged contact with floodwaters without sustaining any significant damage that requires more than cosmetic repair".

\section{Discussion}

\subsection{Weriagar District existing condition}

Site condition were collected on the Site Survey on May 2014.

\subsubsection{Water availability and sanitation system}

The water with high salinity enter into the bay and mix with low salinity water so it causes mixing between the fresh water masses and bay water stuck in the head of bay. This factor was the one that make it difficult in finding clean water. Based on the information gathered from the site survey, the water available is mostly infected with $\mathrm{E}$. Coli bacteria and is overly salty. That condition of water is unsuitable to be used for daily purposes for the villagers in the Weriagar District Area. The infected clean water in this area is caused by contamination from waste water of the existing houses. At the moment, there are no waste water sanitation system available.

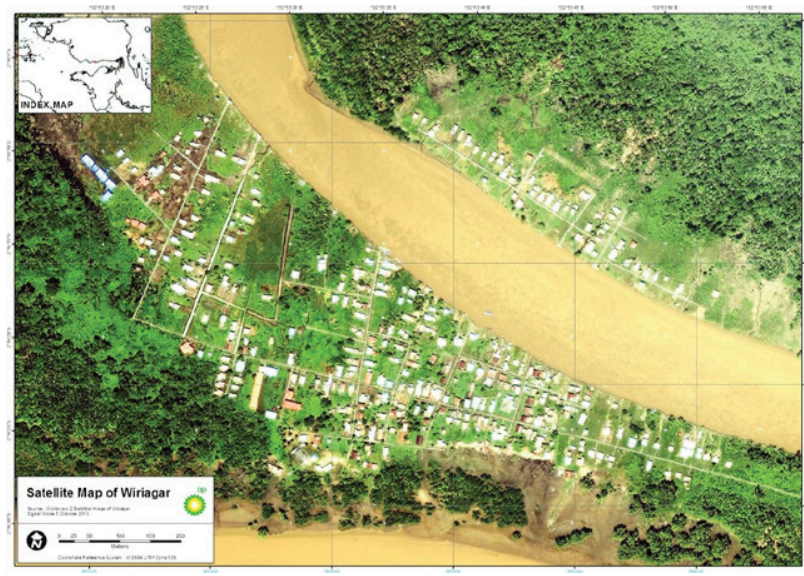

Figure 1. Site MAP

\subsubsection{Green area and vegetation}

The riverbank areas and seaside that have the heaviest process of erosion and abrasion are those where the natural cover has been disturbed and that have become an open land (Figure 1). Nature can no longer be a supporting and inhibiting element of the rate of erosion due to the fact that local plants such as Nypa palm and mangrove forests have lost their media to be able to grow back naturally. Built environment especially in the dense area of the village have experience the most serious degradation in its environment and spatial quality with the decrease of green open spaces (Figure 2). These green open spaces are supposed to be inhibiting the rate of the tide that erodes the fertile soil layer on the wet land.

\subsubsection{Building materials}

The use of local materials becomes dominant because of limited availability of materials from the outside area and lack of supporting accessibility to send the material into the site. The local materials have been processed beforehand to ensure their strength, durability and to facilitate their maintenance. Local materials are used as structural elements of the building and as well as cover the walls of the building. Wood is the dominant material used in the existing buildings found in the Weriagar District Area. However, the fact that materials used in residential buildings are mainly unprocessed, local materials or raw materials indicate that the construction quality does not meet appropriateness standards especially those related to durability against weather condition.

\subsection{Development of design criteria}

\subsubsection{Site plan design criteria}

Some principles were used as consideration in arranging Weriagar District site plan (Brenn \& Rigby, 1994):

- Geographical conditions: such as water, soil and climate affect the engineering, design, and construction on the development area. To prevent soil erosion and abrasion in Weriagar District that often

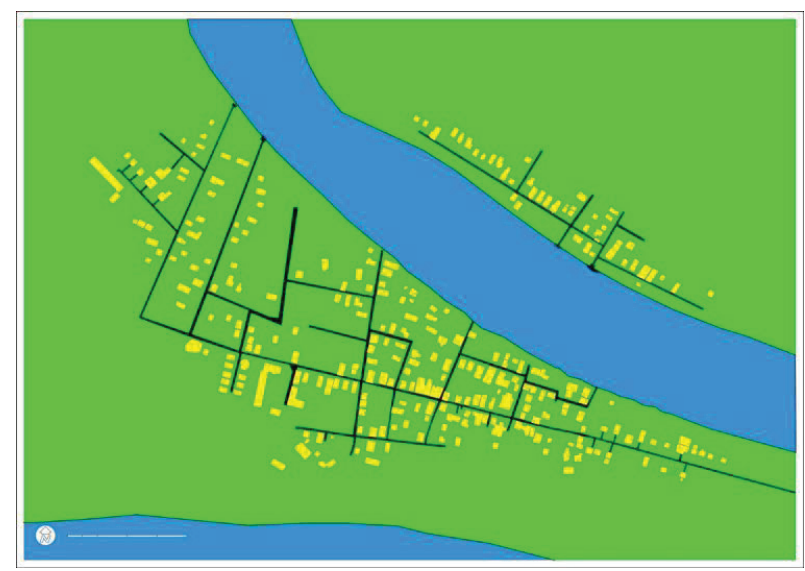

Figure 2. Green Area in Weriagar District 
happened, it is necessary to make structural protection. The tidal conditions also have to be considered in the design of the building and walkway in Weriagar District.

- Image of Region: a visual image of character which captured when seeing a region to be maintained and created in the Weriagar District is natural and comfortable coastal village.

- Accessibility: Existing access in this area should be supported by improving its infrastructure. Weriagar district can only be accessed via the water lane, especially the river. Therefore, the jetty dock and boat dock is the important basic infrastructure. While in the area there is a walkway as the main circulation infrastructures.

- Administrative Boundaries: The boundaries of the land ownership/community rights, village boundaries that should not change, and the minimum number of resident remain the same.

- The building in this region is dominated by houses and public infrastructure. The building is generally a house on stilts made of wood material. Tidal condition affecting the floor level of the house and social facilites, as well as the surface level of walkway as public infrastructure. The highest tidal water level measured is approximately $1 \mathrm{~m}$, therefore the floor level of the house and social facilities were designed above the tide level, approximately $1.5 \mathrm{~m}$ from the existing ground level. Meanwhile, the surface level of the walkway is $1.3 \mathrm{~m}$ from the existing ground. The distance between the new houses on either side is at least $6 \mathrm{~m}$, and the distance to the front porch of the main walkway is at least $3 \mathrm{~m}$.

- Landscape Arrangement is indispensable especially in the border areas of the river and coast area. The potential of erosion and abrasion is very high.

- Completeness infrastructure of region: Weriagar district as one administrative area in Bintuni Bay Regency, need to have regional infrastructure. Public infrastructure consists of a walkway, drainage, boat dock, and the Social Facilities were Sanggar Pemuda, Posyandu and a football field.

- Social and Cultural: Culture and habits of the local people should not be overlooked in settlement improvement program. There are many social and historical values that are embedded in their living that made a principle of life for the next generations, such as ceremonies when moving house, sacred house, do routine activity in the edge of the river and many other things.

- Regulation: The estuary area has a variety of restrictions or rules in size and complexity. Thus, in the arrangement Weriagar District need to consider regulation of river border, coastal border, and emphasizes the protection of the environment and restore natural function as an area that is always experiencing tidal conditions.

\subsubsection{House design criteria has some points that must} be suits with the site condition, such as:

\section{Climate}

The design creates a new identity that responds to its climate and context. The main purpose of building is to give its occupants comfort inside the building. The comfort parameters include (Kay \& Alder, 1999): (a) Natural Daylight and Heat Control; Natural lighting is what the design seeks the most. The building has to design not too wide so that the sun can reach into innermost room. Points to control are, the form of building mass; the pattern, position, and shape of building openings; the system of building's cover and shade control of building. (b) Air Circulation and $\mathrm{Hu}-$ midity Control; Good air circulation, especially inside the building, makes the occupants able to do the activity well (Figure 3). The more opening in the lower side of the building allows air to flow inside, while the opening in the upper side pulls the air below and get it out from the building. This air movement is the optimal condition of the building.

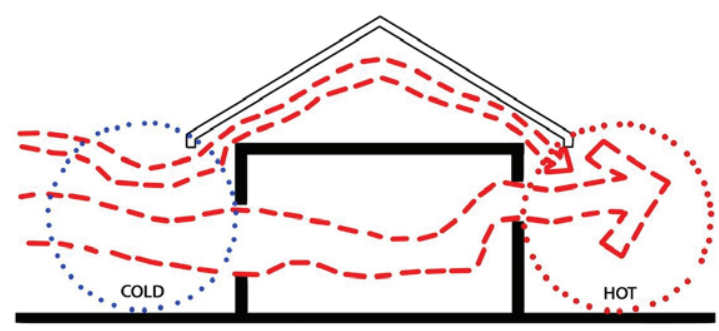

Figure 3. Air circulation diagram

\section{Functionality}

Building design with modular system to accommodate typical functions is applied in every room of the house. Modular system is a way to keep the buildings in unity. The modular system leads to easiness in design and construction process. Open layout system allows function flexibility, adaptive to function, interior layout change, and easiness for development and expansion of building module and mass.

\section{Design Character and Façade}

Design character of the buildings gives the most impression about the character of the house itself. Vernacular character is contextual with local and cultural condition of Weriagar District. The house design has to represent the local richness by applying it in the design elements.

\section{Constructability}

Another aspect that should be considered is the easiness in the building construction process. The building material has to be fixed in early design process. It will decide how large a space can be or how tall the building will be. The material should be surveyed to make sure its availability in the location. With large number of availability, the construction can be carried out using the same material to avoid social gap. The structural modular system is benefit guideline in the initial design process as well as each development. 


\subsection{Design concept}

\subsubsection{Design concept of Weriagar district settlement plan}

- Housing Arrangement Concept

Based on the analysis of neighborhood space usage, community activities, and the layout of the existing building, as well as the structuring principle of settlement in estuary there are several concepts used in the arrangement of the house (Figure 4). Building Boundary Line Determination is based on security considerations, health, comfort, and harmony with the environment as well as the building height.

- Public Infrastructure Arrangement Concept

The public infrastructure items in Weriagar District are Walkway, Drainage and Boat Dock (Figure 5). The arrangement of the new Walkway path follow the existing walkway path. Walkway path aims to connect each village in the Weriagar Disrict, ease for the people to access boat dock and jetty as the main transportation, and to anticipate tidal conditions.

Drainage system arrangement aimed to speed up the flow of the tides and the flow of surface water to get out from the landside. Drainage was placed on one side of walkway to ease inspection. In drainage system, water flow that coming out from the site will be heading to the river. Arrangement of boat dock that serves as transportation

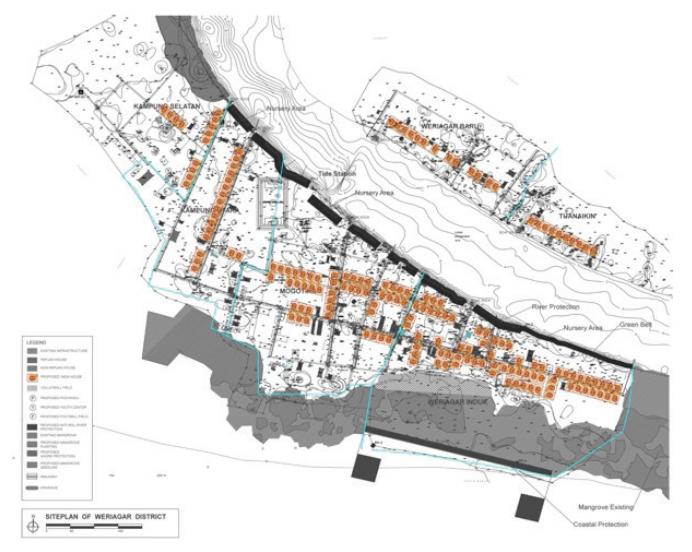

Figure 4. Arrangement pattern of house

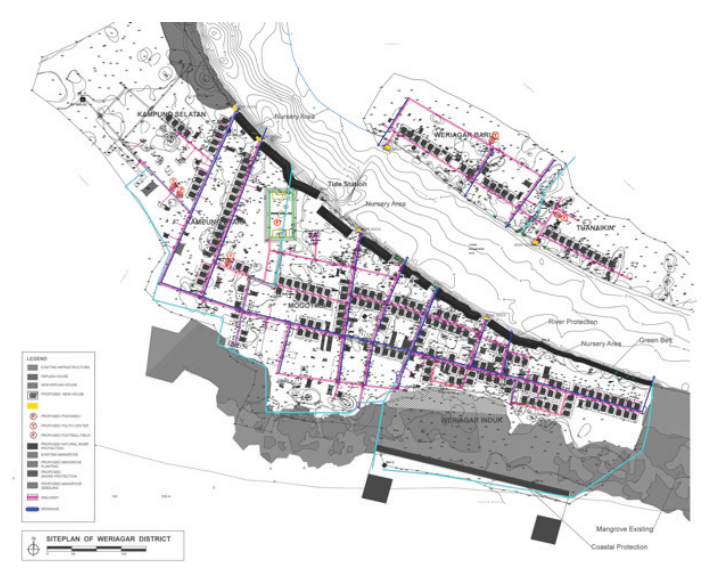

Figure 5. Arrangement pattern of public infrastructure infrastructure for small boat belonging to people who used daily both as a mode of transportation.

- Social Facilities Arrangement Concept

Social facilities are facilities, equipment, or installations that constructed and needed for the proper function of society system especially in social service system (Figure 6). The purpose is to equate the distribution of social facilities in each village and to realize people aspirations and community needs.

- River Boundary Line and Coastal Boundary Line Arrangement Concept

River and coastal in Weriagar District planned to be built an embankment as protection from erosion and abrasion, then the boundary line rules of river and embankment coastal (Figure 7). Therefore, the river boundary line in Weriagar District at least 5 meters from the outer side of the embankment. Based on consideration to natural protection from abrasion and geobag protection from community activities, the river boundary line space will add 5 meters to 10 meters to plant Nypa palm. Based on national regulation that states the maximum building height is 15 meters and coastal boundary line is at least 100 meters, the site plan must be accommodated the 100 -meter border and then planted with mangroves. Mangroves planting is intended as one of the efforts to protect the beach from erosion (Peraturan Pemerintah Republik Indonesia no. 47 Tahun..., 1997).

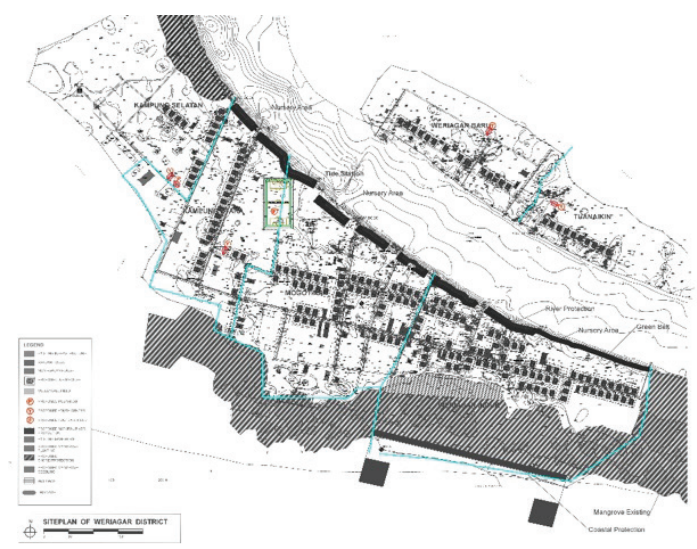

Figure 6. Arrangement pattern of social facilities

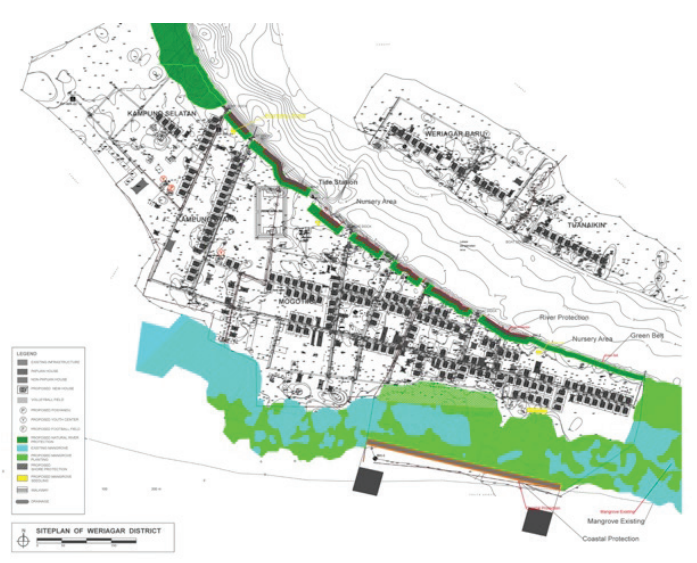

Figure 7. Arrangement pattern of river border and coastal border 


\subsubsection{Building concept}

\section{- General Concept}

Based on the analysis result of space usage preferences, inhabitant's activities, and existing house layout, the following recommendations on house layout are made, house layout should follow daily activity pattern, should follow room usage and function pattern that different from public buildings, should consider the building growth to anticipate additional room needs which have not been fulfilled in the initial house construction stage. The house shape and character should still be maintained while integrating original and additional parts (Departemen PU. Dirjen Cipta Karya, 1999).

- Building Mass and Form

The concept of the building mass is to express the traditional aspect of Weriagar District local house. The building is adapted from the existing traditional house found in Weriagar District (Figure 8). One of the main identity of a Weriagar House is the elevated system of the house. The house floor is elevated at the maximum height of the water from the river located near the site, as a response to the swampy and wet soil condition. The elements which is adapted from the Weriagar District traditional house is the high-pitched roof. Not only to create the traditional expression of the house, but also to use natural ventilation system (Undang-undang No. 28 Th 2002...).

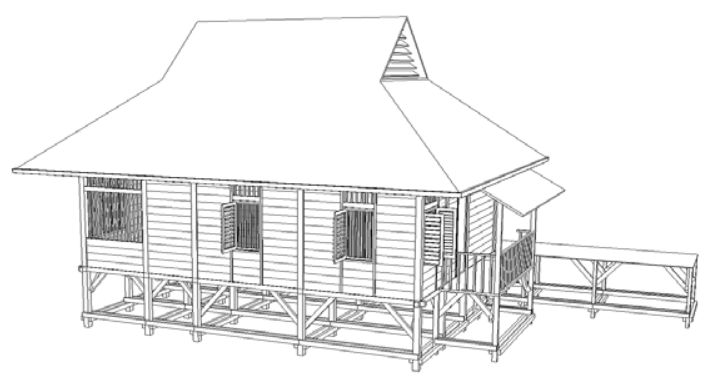

Figure 8. Building mass

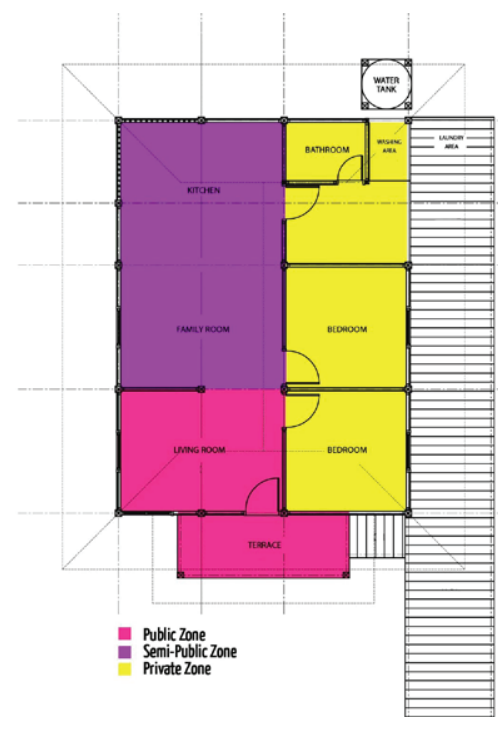

Figure 9. Zoning diagram
The roofing system was modified from the old traditional roofing system by adding vents at both sides of the roof. The purpose is to allow the trapped hot/warm air in the roof to flow through (crossing ventilation). The circulation of air in the roof will decrease the number of heat that received inside the house.

\section{- Zoning}

Zoning in the house designed based on function of space to anticipate the presence of space that has not been fulfilled at the early construction so the house character can still be maintained (Figure 9). The zones in the house divided into three zones, they are the public zone, the semi-public zone, and the private zone. The positioning of the zones is shown in the diagram above.

\section{- Air Circulation}

One design approach for the indigenous people in Weriagar District Area is the natural ventilation to provide good indoor environment quality (Figure 10). It maintains a healthy, comfortable, and productive indoor climate. Natural ventilation systems rely on pressure differences to move fresh air through buildings. The amount of ventilation will depend on the placement of openings in the building.

- Water Treatment

Due to the site condition where the clean water supply system is still insufficient to the needs of the people, rain water harvesting is one of the solution applied in this housing design. The roof of the house was designed to tilt in four directions and completed with gutters in all four sides (Figure 11). The gutters will collect the rainwater which then be channelled into the water tank provided at

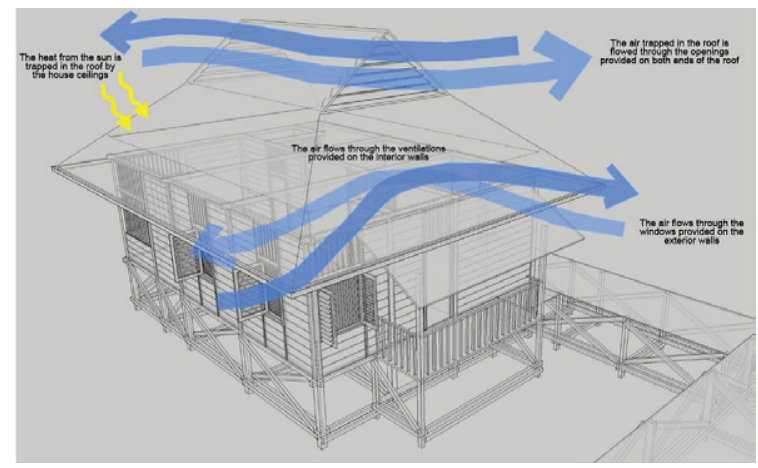

Figure 10. Air circulation concept

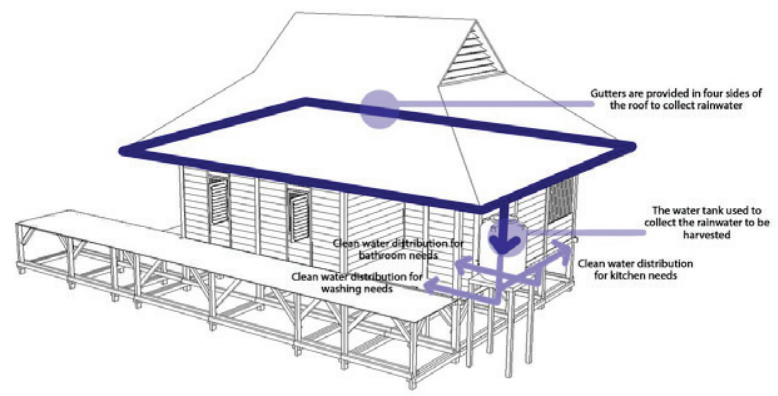

Figure 11. Water treatment concept 
the back of the house. The water tank is equipped with a filter system using a sheet of gauze placed on the openings of the water tank to ensure that the water that enters the water tank is free from dirt. By using the filter, the rain water held in the tank can directly be used for daily needs in the house.

- Natural Lighting

Lighting is one of the most critical qualities of an indoor space. Exposure to natural light can be the solution to create a comfortable space inside the house. In Weriagar District Area, electricity is still limited. The indigenous people still relies on solar machine (genset) as the energy source. With that condition, natural lighting is one of the important concept to be used in this design. The diagram shows that the house design enables sunlight to enter the house easily as natural lighting (Figure 12). But the roof is designed wide enough to prevent the heat from the sun to enter in the middle of the day. This is intended to prevent the house users to feel overly heated during the day.

- Building Material

Weriagar District is located in the remote area with difficult access, so the usage of materials both of component and systems structure using local material that are easily found on the location of the design will minimize the cost of shipping materials. The material must be processed beforehand so the quality of construction can fulfil the building standard of comfort and can be adapted with weather conditions in the region, and the material chosen

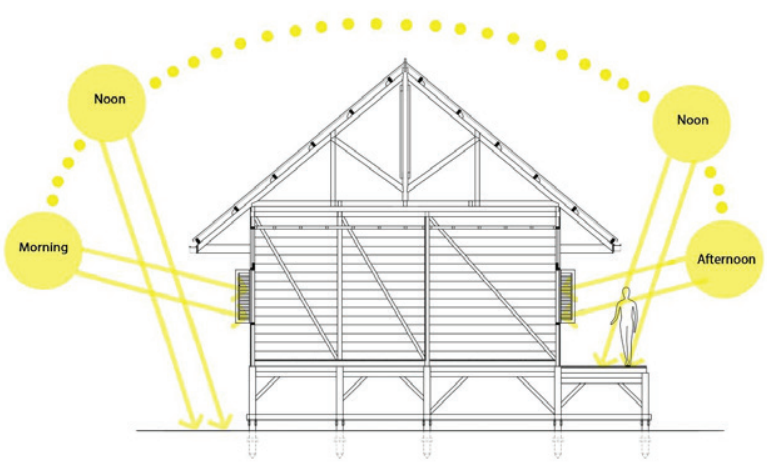

Figure 12. Natural lighting concept

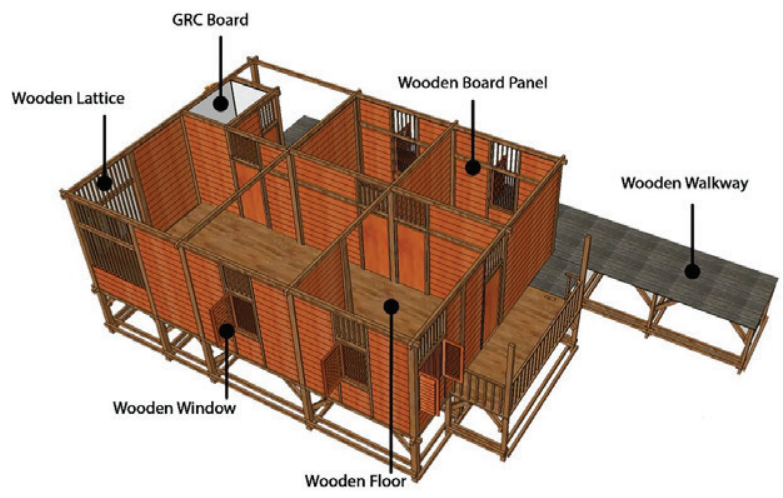

Figure 13. Building material concept is wood (Figure 13). Wood is the dominant material used in the existing buildings found in the Weriagar District Area.

\section{- Modular Structure System}

A modular structure is used as an approach to reduce cost (due to less customization and shorter learning time) and to offer flexibility in the house design. The module used in this housing design varies in the multiple of 1,50 $\mathrm{m}, 2,00 \mathrm{~m}$, and $3,00 \mathrm{~m}$. The smallest module used has the length of $1,50 \mathrm{~m} \times 2,00 \mathrm{~m}$. While the biggest module used has the length of $3,00 \mathrm{~m} \times 3,00 \mathrm{~m}$. The length of the module used is based on the availability of the material in the area.

\section{Conclusions}

Weriagar District is included into the category of settlement in the estuary area by its location in the coastal area that flanked by river and sea. By developing criteria and concept design based on resilient design principle and criteria, The Tropical Shore Settlement Improvement Program attempt to upgrading physical condition of Weriagar District and to support and improve quality of life of communities in the Bintuni Bay and beyond by providing a reliable and selected resources. Some of the design criteria for the settlements in the estuary area are divided into two concepts. Site plan concept that describes the fulfilment of criteria design used as consideration in structuring the site plan Weriagar District and the concept building based on analysis result of space usage preferences, inhabitant's activities, existing house layout and design criteria for buildings in estuary areas.

\section{References}

Bengen, D. G. (2004). Menuju Pengelolaan Wilayah Pesisir Terpadu Berbasis Daerah Aliran Sungai (DAS), dalam Interaksi daratan dan Lautan. Jakarta: Kedeputian Ilmu Pengetahuan Kebumian, Lembaga Ilmu Pengetahuan Indonesia.

Brenn, A., \& Rigby, D. (1994). Waterfronts: cities reclaim their edge. New York: McGraw-Hill Professional Publishing.

Departemen PU. Dirjen Cipta Karya. (1999). Petunjuk Teknis Pembangunan Perumahan Nelayan. Dep. PU. Jakarta.

Firmansyah, Tamin, R. Z., Rante Allo, I. P., \& Wulanningsih, R. (2017, November 14). Concept select matrix development as decision-making tools of housing and settlement imrovement plan in Weriagar District, Bintuni Bay. Presented on HABITechno International Seminar - Ecoregion as a Verb of Settlement Technology and Development, 2017. Departement of Architecture, School of Architecture, Planning, and Policy Development, Insititut Teknologi Bandung.

Kay, R., \& Alder, J. (1999). Coastal planning and management. Spon Press (Routledge).

Kusliansjah, K., \& Suriansyah, Y. (2013). RAFTA2011, the innovation of the manufactured floating house model: a new concept of waterfront settlements for flood risk reduction in Indonesia. The International Journal of Engineering and Science 2013, 2(8), 18-29.

Peraturan Pemerintah Republik Indonesia no. 47 Tahun 1997 tentang Tata Ruang Wilayah dan Peraturan Menteri Pekerjaan 
Umum No.63/PRT/1993 tentang Garis Sempadan Sungai, Daerah Manfaat Sungai, daerah Penguasaan Sungai dan Bekas Sungai.

Supriharyono. (2007). Konservasi Ekosistem Sumber Daya Hayati. Pustaka Pelajar. Yogyakarta.

Undang-undang No. 28 Th 2002 mengenai Bangunan Gedung dan Peraturan Menteri Pekerjaan Umum Nomor: 29/PRT/M/2006 Tentang Pedoman Persyaratan Teknis Bangunan Gedung.

Watson, D., \& Adams, M. (2011). Design for flooding architecture, landscape, and urban design for resilience to flooding and climate change. New Jersey: John Wiley \& Sons, Inc. Hoboken.

Weinstein, M. P. (2008). Ecological restoration and estuarine management: placing people in the coastal landscape. Journal of Applied Ecology 2008, 45, 296-304.

https://doi.org/10.1111/j.1365-2664.2007.01355.x

Wicaksono, B., Siswanto, A., Kusdiwanggo, S., \& Anwar, W. F. (2016). Cultural approach of sustainability in dwellings culture Riparian Community Musi River Palembang. DIMENSI - Journal of Architecture and Built Environment, 43(2), 85-92.

Wijanarka. (2008). Desain Tepi Sungai. Ombak, Yogyakarta. 